\title{
EFEKTIVITAS RELAKSASI AUTOGENIK TERHADAP KECEMASAN PASIEN
}

\author{
Noviyana Prasasti ${ }^{1 *}$, Welmi Solihat ${ }^{2}$, Rani Waily ${ }^{3}$, Ruth Alferina ${ }^{4}$, Diana Solla ${ }^{5}$, Anung Ahadi \\ Pradana $^{6}$ \\ 1. Program Studi S1 Keperawatan Ekstensi, STIKes Mitra Keluarga, Bekasi-Indonesia \\ 2. Program Studi S1 Keperawatan Ekstensi, STIKes Mitra Keluarga, Bekasi-Indonesia \\ 3. Program Studi S1 Keperawatan Ekstensi, STIKes Mitra Keluarga, Bekasi-Indonesia \\ 4. Program Studi S1 Keperawatan Ekstensi, STIKes Mitra Keluarga, Bekasi-Indonesia \\ 5. Program Studi S1 Keperawatan Ekstensi, STIKes Mitra Keluarga, Bekasi-Indonesia \\ 6. Program Studi DIII Keperawatan, STIKes Mitra Keluarga, Bekasi-Indonesia
}

Korespondensi: Noviyana Prasasti | STIKes Mitra Keluarga | noviyanaprasasti@ gmail.com

\begin{abstract}
Abstrak
Pendahuluan: Gangguan mental emosional yang bermanifestasi sebagai gangguan kecemasan dan depresi sehingga dapat mempengaruhi pasien dalam menjalani proses penyembuhan, relaksasi autogenik diketahui menjadi salah satu dari terapi komplementer yang dapat memberikan efek positif terhadap kondisi kecemasan yang dialami oleh pasien.

Metode: Penulis melakukan studi literatur dengan pendekatan sederhana terhadap 10 artikel tentang efektifitas pemberian terapi relaksasi autogenik atau autogenic training. Metode yang digunakan dalam penumpulan artikel pada databasegoogle scholar. Sumber referensi dipilih menggunakan metode Problem, Intervention, Comparison, Outcomes (PICO) dengan batasan artikel yang diterbitkan dari tahun 2016-2021.

Hasil: Hasil yang didapatkan adalah pemberian terapi relaksasi autogenik cukup efektif untuk menurunkan tingkat kecemasan yang dialami oleh pasien dalam berbagai kondisi

Kesimpulan: Kesimpulan dari penulisan ini adalah mengingat relaksasi autogenik adalah salah satu terapi yang membutuhkan keahlian khusus dalam pelaksanaannya kepada pasien, maka tenaga kesehatan perlu mempertimbangkan untuk menguasai metode relaksasi autogenik agar dapat membawa hasil yang signifikan bagi pasien.
\end{abstract}

Kata Kunci: Kecemasan, Relakasi autogenik, Terapi komplementer.

Diterima 16 November, 2021; Accepted 30 Desember, 2021

\section{PENDAHULUAN}

Di indonesia Prevalensi terkait gangguan kecemasan menurut hasil Riset Kesehatan Dasar (Riskesdas) pada tahun 2013 menunjukkan bahwa sebanyak 6\% populasi usia 15 tahun ke atas sekitar 14 juta penduduk di Indonesia mengalami gangguan mental emosional yang bermanifestasi sebagai gangguan kecemasan dan depresi (Kementrian Kesehatan RI 2014). Cemas ditandai oleh perasaan takut atau ketakutan yang sangat dan dapat muncul dengan bentuk gejala fisik seperti palpitasi, mual, pusing, perasaan sesak nafas, tremor, berkeringat atau diare. (Kementrian Kesehatan RI 2014).

Terapi komplementer dan alternatif merupakan suatu intervensi untuk menigkatkan, memelihara, menjaga kesehatan dan kesejahteraan, mencegah penyakit, dan menurunkan gejala yang dialami individu (kanker, peyakit jantung, diabetes, artritis, nyeri kepala, gangguan leher, hipertensi, strain dan sprain, juga gangguan tidur (Solehati 2015).

Sebagi pemberi asuhan, peran perawat sangat penting dalam proses penyembuhan klien, salah satunya dalam penanggulangan kecemasan. Dalam hal ini perawat berupaya mengurangi kecemasan yang dialami klien melalaui asuhan keperawatan yang diberikan. Salah satunya dengan cara pemberian terapi relaksasi. Contoh dari relaksasi ialah relaksasi autogenic. Relaksasi autogenic adalah relaksasi dengan penyampaian sugesti positif yang membuat efek relaksasi psikologis dan pada akhirnya akan didapatkan efek anxiolitik (Vidas M smalc 2017)

Berdasarkan uraian diatas, penulis tertarik dalam pengaruh relaksasi autogenic dalam mengurangi kecemasan. Beberapa study telah dilakukan untuk mengatasi kecemasan dengan menggunakan autogenic training. Oleh sebab itu, tujuan dari literature review ini adalah untuk mengetahui pengaruh dari Relaksasi autogenic atau autogenic training untuk mengurangi kecemasan . 


\section{METODE}

Pencarian literatur dilakukan dengan mengidentifikasi semua jenis artikel mengenai efek autogenic training terhadap kecemasan. Database yang digunakan adalah google scholar. Hasil pencarian dibatasi tahun 2016 sampai tahun 2021.serta secara manual memilih artikel yang relevan atau sesuai dengan pertanyaan penelitian. Kata kunci yang digunakan meruapakan gabungan dan kombinasi dari beberapa kata anatara lain "relaksasi autogenic" dan "kecemasan". Kriteria inklusi pada artikel ini ialah :(1) Artikel menggunakan bahasa Indonesia atau bahasa Inggris,Intervensi yang digunakan adalah relaksasi autogenic, (3) Hasil penelitian menunjukan adanya pengaruh autogenic training terhadap kecemasan, sedangkan kriteria eksklusi adalah penelitian yang tidak relevan dengan pertanyaan penelitian.

\section{HASIL}

Berdasarkan hasil penulusuran didapatkan 10 artikel yang membahas tentang penggunaan autogenic training dalam menurunkan kecemasan pasien. Beberapa penelitian telah membuktikan bahwa dengan latihan relaksasi autogenic terbukti dapat menurunkan kecemasan pada pasien di berbagai tindakan keperawatan seperti contoh untuk mengurangi kecemasan pada panderita kanker, end stage renal khususnya pada tindakan hemodialisis, kecemasan pada penderita hipertensi, diabetes melitus serta kecemasan pada ibu primigrivida pada tindakan proses persalinan. Sumber yang digunakan diambil dari beberapa jurnal dalam 5 periode terahir dapat dilihat pada tabel 1 .

Tabel 1. Analisis Sumber Literatur yang Dipergunakan

\begin{tabular}{|c|c|c|c|c|}
\hline No & Penulis & Judul & Hasil & Kesimpulan \\
\hline 1. & $\begin{array}{l}\text { Pryati } \\
\text { Rihi, } \\
\text { Muflihatul } \\
\text { Muniroh, } \\
\text { Dwi } \\
\text { Susilawati } \\
(2020)\end{array}$ & $\begin{array}{l}\text { Relaxation Therapy } \\
\text { On The Level Of } \\
\text { Anxiety Of Post } \\
\text { Sectio Caesarea: A } \\
\text { Literature Review }\end{array}$ & 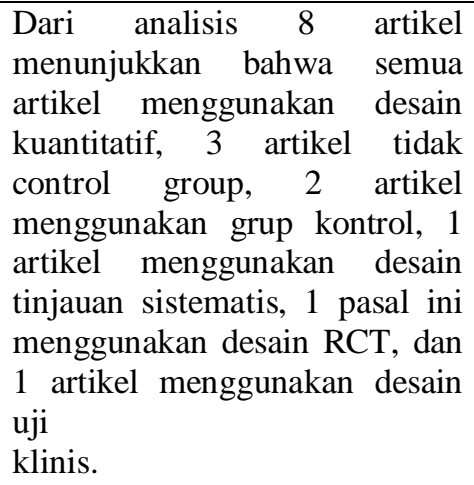 & $\begin{array}{l}\text { Dari } 8 \text { artikel penelitian sebelumnya } \\
\text { menunjukkan bahwa terapi relaksasi } \\
\text { efektif dalam mengurangi tingkat } \\
\text { kecemasan ibu. Meskipun ada berbagai } \\
\text { jenis teknik relaksasi relaksasi autogenik } \\
\text { memiliki ukuran efek sedang-tinggi dan } \\
\text { direkomendasikan untuk kecemasan } \\
\text { dibandingkan dengan teknik relaksasi } \\
\text { lainnya. }\end{array}$ \\
\hline 2. & $\begin{array}{l}\text { Chika } \\
\text { Minowa } \\
\text { and } \\
\text { Kikuyo } \\
\text { Koitabashi } \\
(2012)\end{array}$ & $\begin{array}{lr}\text { Effects } & \text { Of } \\
\text { Autogenic } & \text { Training } \\
\text { On Perioperative } \\
\text { Anxiety And Pain In } \\
\text { Breast } \\
\text { Patients }\end{array}$ & $\begin{array}{l}\text { Kelompok Autogenic training } \\
\text { memiliki kecemasan yang } \\
\text { menurun secara signifikan } \\
\text { selama tiga hari pascaoperasi. } \\
\text { Skor nyeri pasca operasi juga } \\
\text { menurun secara signifikan, } \\
\text { meskipun fakta bahwa kedua } \\
\text { kelompok telah menerima } \\
\text { jumlah analgesik yang setara. } \\
\text { Tidak ada signifikan secara } \\
\text { statistik perbedaan diamati } \\
\text { antara kelompok-kelompok } \\
\text { dalam persyaratan analgesik } \\
\text { mereka. }\end{array}$ & $\begin{array}{l}\text { Autogenic training menggunakan } \\
\text { pendekatan non-farmakologis yang } \\
\text { berguna untuk menghilangkan kecemasan } \\
\text { dan rasa sakit segera setelah kanker } \\
\text { payudara bedah. }\end{array}$ \\
\hline 3. & $\begin{array}{l}\text { Indah Nur } \\
\text { Imamah } \\
(2020)\end{array}$ & $\begin{array}{l}\text { The Effect Of } \\
\text { Autogenic } \\
\text { Relaxation On Blood } \\
\text { Pressure } \\
\text { Changes In } \\
\text { Patients With } \\
\text { Hypertension }\end{array}$ & $\begin{array}{l}\text { Hasil analisis menunjukkan } \\
\text { bahwa ada efek relaksasi } \\
\text { autogenik pada tekanan darah } \\
\text { pada pasien hipertensi. } \\
\text { Relaksasi autogenik dapat } \\
\text { menguntungkan perubahan } \\
\text { tekanan darah pada pasien } \\
\text { hipertensi dan cocok jika }\end{array}$ & $\begin{array}{l}\text { Intervensi relaksasi autogenik yang } \\
\text { diberikan kepada pasien hipertensi secara } \\
\text { teratur selama dua tiga kali sehari telah } \\
\text { terbukti memberikan manfaat untuk } \\
\text { perubahan tekanan darah. Jika ini } \\
\text { intervensi dilakukan bersamaan dengan } \\
\text { tindakan kolaboratif yang tepat, dapat } \\
\text { memberikan hasil maksimum untuk }\end{array}$ \\
\hline
\end{tabular}


dilakukan secara teratur.

4. Andayani Pengaruh Pemberian

Boang Relaksasi Autogenik

Manalu, TerhadapTingkat

Nurul

Aini

Siagian Kecemasan Ibu Primigravida Di

Mutiara

Dwi

Yanti BPM

Kurnia

Kecamatan Deli Tua

Kabupaten

Putri

Ayu Yessy

Ariescha,

Dewi

Tiansa

Barus

Tetty

Junita

Purba

(2020)

5. Yulia Nur Penerapan Relaksasi

Hayati, Autogenik Untuk

Emilia Mengurangi

Puspitasari Kecemasan

Sugiyanto Pasien

(2019) Melitus

Pada

Diabetes
Berdasarkan hasil penelitian dengan menggunakan uji $\mathrm{T}$-tes penelitian ini dapat disimpulkan pada pretest dan posttest dengan sampel 20 responden memiliki rata-rata sebelum (mean= 32,95), standar deviasi sebesar7,790 sedangkan pada kelompok posttest dengan sampel 20 responden memiliki rata-rata sesudah (mean= 15,95), standar deviasi sebesar 3,748 dengan P-value $(0,001)<$ $\alpha$

0,05 maka H0 ditolak Ha diterima yang artinya terdapat Pengaruh Pemberian Relaksasi Autogenik Terhadap Tingkat Kecemasan Ibu Primigravida Di BPM Kurnia Kecamatan Deli Tua Kabupaten Deli Serdang Tahun 2020.

Setelah dilakukan tindakan tersebut masing - masing pasien baik pasien I dan II dalam kategori sedang dan ringan. hasil skor skala tingkat kecemasan pada pasien I yaitu 60 (kecemasan sedang) dan pasien II yaitu 45 (kecemasan ringan). Berikut adalah table penjelasan tanda gejala pasien I dan II, dimana pasien I dan I pasien Hipertensi.

1. Tingkat Kecemasan Ibu Primigravida Di BPM Kurnia Kecamatan Deli Tua Kabupaten Deli Serdang sebelum diberikan perlakuan dapat diketahui bahwa dari 20 responden memiliki nilai min adalah 21 dan max adalah 50 serta mean atau Rerata 32,95.

2. Tingkat Kecemasan Ibu Primigravida Di BPM Kurnia Kecamatan Deli Tua Kabupaten Deli Serdang sesudah diberikan perlakuan dapat diketahui bahwa dari 20 responden memiliki nilai min adalah 10 dan max adalah 23 serta mean atau Rerata 15,95.

3. Terdapat Pengaruh Pemberian Relaksasi Autogenik Terhadap Tingkat Kecemasan Ibu Primigravida Di BPM Kurnia Kecamatan Deli Tua Kabupaten Deli Serdang Tahun 2020 dengan (Pvalue $0,001<\alpha 0,05)$

Kecemasan pada kedua pasien diturunkan dengan pemberian terapi relaksasi autogenik, penurunan skor kecemasan pada pasien I yaitu 60 dengan kecemasan sedang menjadi 49 kecemasan ringan dan penurunan pada skor nilai kecemasan pada pasien II yaitu 45 yaitu kecemasan ringan menjadi 39 normal atau tidak cemas. Nilai kecemasan pada pasien I dan pasien II saat terakhir berbeda karena pasien II lebih pandai untuk mengontrol kecemasannya dibandingkan pasien I meskipun pada awalnya kedua pasien sama-sama belum mengetahui kecemasan pada penyakitnya. Hal I I terjadi karena relaksasi otogenik memberikan sensasi tenang, ringan, dan hangat yang akan menyebar ke seluruh tubuh dan memberikan efek kehangatan yang bisa dirasakan oleh pasien.

Karakteristik responden pada kedua kelompok adalah responden lebih banyak terdiri dari perempuan, suku betawi, pendidikan Sekolah Dasar, sebagai Ibu Rumah Tangga, memiliki riwayat hipertensi lebih 1 tahun, tidak memiliki penyakit lainnya, tidak ada riwayat keluarga dengan hipertensi dan tinggal serumah dengan pasangan (suami/istri). Kesimpulan akhir diketahui terdapat perbedaan tekanan darah sistolik dan tingkat kecemasan responden setelah dilakukan intervensi relaksasi otot progresif (nilai $\mathrm{p}=0.000$ ). 


\begin{tabular}{|c|c|c|c|c|}
\hline 7. & $\begin{array}{l}\text { Rosdiana } \\
\text { Saputri, } \\
\text { Desi } \\
\text { Ariyana } \\
\text { Rahayu } \\
(2019)\end{array}$ & $\begin{array}{lr}\text { Terapi } & \text { Autogenik } \\
\text { Terhadap } & \text { Kondisi } \\
\text { Psikologi } & \text { Pasien } \\
\text { CKD } & \text { Yang } \\
\text { Menjalani } & \\
\text { Hemodialisis } & \end{array}$ & $\begin{array}{l}\text { Hasil uji statistik pada } \\
\text { kelompok intervensi terdapat } \\
\text { efektivitas terapi autogenik } \\
\text { terhadap penurunan tingkat } \\
\text { depresi, ansietas dan stres } \\
\text { dengan masing- masing p } \\
\text { value }=0,000 \text {. }\end{array}$ & $\begin{array}{l}\text { Secara statistik ada efektifitas terapi } \\
\text { autogenik dalam menurunkan depresi } \\
\text { pada pasien CKD yang menjalani } \\
\text { hemodialisis di tandai dengan ratarata } \\
\text { skor depresi sebelum dan sesudah } \\
\text { diberikan terapi relaksasi autogenik yaitu } \\
5.00 \text { menjadi } 2.00 \text { dan nilai } p=0,0001 \text {. }\end{array}$ \\
\hline 8. & $\begin{array}{l}\text { Nova } \\
\text { Natalia } \\
\text { Beba, Elly } \\
\text { L.Sjattar, } \\
\text { Rosyidah } \\
\text { Arafat } \\
(2020)\end{array}$ & $\begin{array}{l}\text { Efektivitas } \\
\text { Autogenic Training } \\
\text { Terhadap } \\
\text { Kecemasan Lansia }\end{array}$ & $\begin{array}{l}\text { Hasil yang diperoleh dari semua } \\
\text { artikel yang pelatihan autogenik } \\
\text { dapat secara signifikan } \\
\text { mengurangi kecemasan pada } \\
\text { orang tua di mana nilai p } \\
<0,001 \text {. }\end{array}$ & $\begin{array}{l}\text { Hasil literature review ini menunjukan } \\
\text { bahwa Autogenic training dapat } \\
\text { direkomendasikan sebagai salah satu } \\
\text { terapi non farmakologis untuk } \\
\text { menurunkan kecemasan pada lansia. } \\
\text { Dalam study ini petugas kesehatan } \\
\text { mempunyai peranan yang sangat penting } \\
\text { karena dapat melakukan autogenic } \\
\text { training tetapi harus memiliki kompetensi } \\
\text { dengan cara mengikuti pelatihan } \\
\text { mengenai autogenic trainin }\end{array}$ \\
\hline 9. & $\begin{array}{l}\text { Dyah } \\
\text { Wijayanti } \\
\text { (2016) }\end{array}$ & $\begin{array}{l}\text { Relaksasi Autogenik } \\
\text { Menurunkan } \\
\text { Kecemasan Pasien } \\
\text { Kanker Serviks }\end{array}$ & $\begin{array}{l}\text { menunjukkan bahwa ada } \\
\text { pengaruh yang signifikan pada } \\
\text { pengurangan kecemasan pada } \\
\text { pasien kanker serviks sebelum } \\
\text { dan sesudah intervensi } \\
\text { autogenik relaksasi dengan } \mathrm{p}= \\
0,011(\mathrm{p}<0,05) \text {. }\end{array}$ & $\begin{array}{l}\text { Kesimpulan dari penelitian adalah bahwa } \\
\text { efek relaksasi autogenik pada kecemasan } \\
\text { pada pasien dengan kanker serviks. } \\
\text { Penelitian lebih lanjut perlu dilakukan } \\
\text { dengan lebih banyak sampel dan } \\
\text { pengujian laboratorium } r \text { melalui } \\
\text { pemeriksaan Endorphin } \beta \\
\text { mendapatkan hasil pengukuran yang } \\
\text { komprehensif. }\end{array}$ \\
\hline 10. & $\begin{array}{l}\text { Sesilia } \\
\text { Bouka } \\
\text { Ni Luh } \\
\text { Widani } \\
(2019)\end{array}$ & $\begin{array}{lr}\text { Pengaruh } & \\
\text { Pendidikan } & \\
\text { Kesehatan } & \text { Pre } \\
\text { Operasi } & \text { dan } \\
\text { Relaksasi } & \text { Autogenic } \\
\text { Terhadap } & \text { Perubahan } \\
\text { Tingkat } & \text { Ansietas } \\
\text { Pasien Pre } & \text { Operasi } \\
\text { di Rs Karitas } \\
\text { Weetebula NTT }\end{array}$ & $\begin{array}{l}\text { Hasil Uji Wilcoxon terdapat } \\
\text { perubahan signifikan pada } \\
\text { ansietas sebelum dengan } \\
\text { sesudah intervensi PenKes dan } \\
\text { RA p }=0,000(<0,05) \text {. }\end{array}$ & $\begin{array}{l}\text { Disarankan kepada perawat untuk } \\
\text { mengajarkan RA kepada pasien dan } \\
\text { melakukan PenKes menggunakan leaflet } \\
\text { sebagai media pembelajaran untuk } \\
\text { mengurangi ansietas sebelum } \\
\text { pembedahan; bagi rumah sakit, dihimbau } \\
\text { agar dapat menyediakan ruangan yang } \\
\text { kondusif sebagai tempat relaksasi atau } \\
\text { untuk diskusi bagi pasien dan keluarga } \\
\text { dengan petugas kesehatan. }\end{array}$ \\
\hline
\end{tabular}

\section{PEMBAHASAN}

Berdasarkan hasil penulusuran yang kami dapatkan bahwa untuk mengurangi kecemasan dapat dilakukan dengan terapi komplementer yaitu autogenic trainingatau relaksasi autogenic yang merupakan suatu latihan yang diciptakan diri sendiri untuk merasakan kehangatan dan sensasi tubuh yang memberat dengan cara menemukan tingkat relaksasi fisik dan ketegangan pikiran sehingga melatih seseorang memasuki fase rileks, yang dapat memberikan keseimbangan mental dan fisik (Richmond, R., 2012) Relaksasi autogenik pada prinsipnya responden harus mampu berkonsentrasi sambil di dalam hati membaca mantra(kalimat-kalimat motivasi) atau zikir maupundo'a bersamaan dengan ekspirasi udara paru (Asmadi, 2012) Pada saat melakukan terapiautogenik ini responden harus lebih fokusberkonsentrasi untuk menurunkan tingkatkecemasan, selain itu pasien harus denganlingkungan tenang, posisi yang nyaman danpikiran yang fokus sehingga pasien dapatrileks dan mengatur pernapasan. D.wijayanti (2019) dalam penelitiannya menyatakan bahwa pelaksanaan relaksasiautogenik membutuhkan kondisi psikologisyang tenang dan tingkat keyakinan spiritualyang baik. Muatan Auto-sugesti yangdilakukan dalam relaksasi autogenik dapatdimodifikasi dengan ucapan do'a sesuaikeyakinan sehingga mengoptimalkan fasepenerimaan alam bawah sadar. Berdasarkan hasil dari beberapa jurnal yang telah kami telaah, menyatakan bahwa autogenic training memberikan nilai yang signifikan dalam menurunkan kecemasan. Dengan demikian salah satu terapi non farmakologi yang bisa di berikan pada lansia yang mengalami kecemasan yaitu autogenic training. 


\section{KESIMPULAN}

Hasil study literatur yang dilakukan penulis tentang terapi non farmakologi berupa latihan relaksasi autogenic efektif dan dapat direkomendasikan untuk menurunkan kecemasan . Dalam study ini petugas kesehatan mempunyai peranan yang sangat penting karena dapat melakukan autogenic training tetapi harus memiliki kompetensi dengan cara mengikuti pelatihan mengenai autogenic training.

\section{REFERENSI}

Andayani Boang Manalu1, Nurul Aini Siagian2, Mutiara Dwi Yanti3, Putri Ayu Yessy. "Pengaruh pemberian relaksasi autogenik terhadap tingkat kecemasan ibu primigravida di bpm kurnia kecamatan deli tua kabupaten deli serdang." Pengaruh pemberian relaksasi autogenik terhadap tingkat kecemasan ibu primigravida di bpm kurnia kecamatan deli tua kabupaten deli serdang (2020): dopler.

Asmadi. Teknik Prosedural Keperawatan,Konsep dan Aplikasi Kebutuhan dasar klien. JAKARTA: Salemba Medika, 2012.

C.Minowa, k.Kitobashi. "Effects of autogenic training on perioperative anxiety and pain in breast cancer patients: A randomized controlled trial." Kitakanto Medical Jurnal (t.thn.).

D.wijayanti. "Relaksasi Autogenik Menurunkan Kecemasan Pasien Kanker Serviks." jurnal keperawatan (2019).

N.Ekarini. P.Kristanti, S.Suratun. "Pengaruh Relaksasi Autogenik terhadap Tingkat Kecemasan dan Perubahan Tekanan Darah pada Pasien Riwayat Hipertensi." jurnal keperawatan poltekkes kemenkes jakarta II (2018): 108-118.

Oktaviani.J. "Jurnal Keperawatan Muhammadiyah Bengkulu." jurnal keperawatan muhamadiyah (2020):51.

P.Rihi, M.muniroh, D.susilowati. "Relaxation Therapy on The Level of Anxiety of Post Sectio Caesarea: A Literatur Review." strada jurnal ilmiah (2020): 1687-1693.

Peran keluarga dukung kesehatan masyarakat. Peran keluarga dukung kesehatan masyarakat. 2016. 21 Juni 2021 <www.kemkes.go.id>.

R.L, Richmond. "A Guide to Psychology and its practice." 2012. A Guide to Psychology and its practice. Monday Juni 2021 <www.Guidetopsychology.com/autog en.htm>.

R.saputri, D.Rahayu. "TERAPI AUTOGENIK TERHADAP KONDISI PSIKOLOGI PASIEN CKD YANG MENJALANI HEMODIALISIS.” Jurnal Ilmu Keperawatan Jiwa V (2019): 139-148.

S.BOUKA, N.Widani. "Pengaruh Pendidikan Kesehatan Pre Operasi Dan Relaksasi Autogenic Terhadap Perubahan Tingkat Ansietas Pasien Pre Operasi Di Rs Karitas Weetebula Ntt." carolus journal of nursing (2019).

Solehati, T \& Kosasih.C.E. Konsep dan aplikasi Relaksasi:Dalam Keperawatan 